\title{
Impacts of Sustainability on Supply Chain Management
}

\author{
Batin Latif Aylak* \\ * Turkish-German University, Faculty of Engineering, Department of Industrial Engineering, İstanbul, Turkey, (ORCID: 0000-0003-0067-1835), batin.latif@tau.edu.tr
}

(2nd International Conference on Applied Engineering and Natural Sciences ICAENS 2022, March 10-13, 2022)

(DOI: 10.31590/ejosat.1075779)

ATIF/REFERENCE: Aylak, B. L. (2022). Impacts of Sustainability on Supply Chain Management. European Journal of Science and Technology, (34), 105-109.

\begin{abstract}
Nowadays, environmental strategies are critical for improving organizational operations. Therefore, sustainable supply chain management plays a key role in supporting organizations improve their overall performance. This paper seeks to determine the level of correlation between sustainability practices and supply chain management within diverse organizational contexts. The research study was facilitated through a systematic review approach. It was based on a data pool consisting of 13 secondary sources that were obtained from online research databases such as Web of Science and Scopus. The sources were subsequently subjected to the exclusion and inclusion criteria. The results obtained indicated that sustainability practices can have a can have a direct and statistically significant impact on organizational operations such as procurement, manufacturing, and logistics, which fall under supply chain management functions. However, it is unclear, whether sustainability practices impacts procurement or logistics processes more. The findings further implied that the implementation of sustainability practices at an organizational level can result in the establishment of novel linkages with partners in the supply chain. The linkages result from the necessity of forming relationships with additional suppliers to obtain relevant resources.
\end{abstract}

Keywords: Supply Chain Managemet, Sustainability, Logistics

\section{Sürdürülebilirliğin Tedarik Zinciri Yönetimi Üzerine Etkileri}

$\ddot{O} \mathbf{z}$

Günümüzde çevresel stratejiler, organizasyonel operasyonların iyileştirilmesi için kritik öneme sahiptir.Sürdürülebilir Tedarik Zinciri Yönetimi bu nedenle, kuruluşların genel performarnslarını geliştirmelerine desteklemede kilit bir rol oynamaktadır. Bu çalışma, çeşitli organizasyonel bağlamlarda sürdürülebilirlik uygulamaları ile tedarik zinciri yönetimi arasındaki korelasyon düzeyini belirlemeyi amaçlamaktadır. Araştırma çalışması, sistematik bir inceleme yaklaşımıyla kolaylaştırılmıştır. Çalışma Web of Science ve Scopus gibi çevrimiçi araştırma veritabanlarından elde edilen 13 ikincil kaynaktan oluşan bir veri havuzuna dayanmaktadır. Bulunan kaynaklar daha sonra çıkartma ve dahil etme kriterlerine tabi tutulmuştur. Elde edilen sonuçlar, sürdürülebilirlik uygulamalarının tedarik zinciri yönetimi fonksiyonlarına giren tedarik, üretim ve lojistik gibi organizasyonel operasyonlar üzerinde istatiksel olarak önemli ve doğrudan bir etkiye sahip olabileceğini göstermiştir. Ancak, sürdürülebilirlik uygulamalarının etkisinin tedarik ve lojistik süreçleri arasında en yüksek olduğu yer net değildir. Çalışmanın bulguları ayrıca, sürdürülebilirlik uygulamalarının kurumsal düzeyde uygulanmasının tedarik zincirindeki ortaklarla yeni bağlantıların kurulumasıyla sonuçlanabileceğini göstermiştir. Bu bağlantılar ilgili kaynakları elde etmek için ek tedarikçilerle ilişkiler kurma gerekliliğinden kaynaklanmaktadır.

Anahtar Kelimeler: Tedarik Zinciri Yönetimi, Sürdürülebilirlik, Lojistik

* Corresponding Author: batin.latif@,tau.edu.tr 


\section{Introduction}

Sustainability practices are increasingly being incorporated into supply chain management within various organizations worldwide. There is extensive public discourse on the most appropriate definition of sustainability [1]. However, most of the definitions are based on ethical, economic, and social perspectives [2]. To get an outlook of what sustainability entails, it is vital to focus on its main processes, which comprise of economic, human, social, and environmental sustainability. Human sustainability is the act of undertaking health, education, and wellbeing-based investments to achieve an all-inclusive sustainability whereby all individuals within a particular social context have sufficient levels of development that can positively affect their behavioral pattern [3]. Conversely, economic sustainability refers to the processes that ensure organizational processes focus on both achieving higher returns on investments and reflecting development in all the aspects of the operation [4].

By contrast, environmental sustainability entails ideologies that focus on aligning green reasoning and raw materials procurement [3]. This alignment is vital in product manufacturing to deliver it to the end-user in a manner that achieves a competitive advantage [5]. Within the previous decade, research studies in the field of supply chain management have veered towards environmental awareness [6]. The trend resulted from the effect of international climate agreements on supply chains within organizations. Social sustainability refers to the procedure of facilitating trade-offs within the supply chain between economic objectives and social responsibilities, to consequently enhance shared value [7]. Business establishments should focus on achieving social sustainability through evaluation of their effect on society and overall performance [8].

One of the advantages to be gained from the incorporation of sustainability practices in supply chain management is the formation of novel collaborations and partnerships [9]. The collaboration with new suppliers is based on sustainable evaluation and selection processes [10]. Additionally, organizational financial gains are achievable upon implementation of sustainable practices. For instance, Nike managed to reduce its labor and material expenses by $50 \%$ and $20 \%$, respectivley, when they applied sustainability practices in their manufacturing processes [11]. Besides, sustainability is fundamental in minimizing the risks of reputational damage [12]. As environmental awareness is increasingly being incorporated into society, more individuals require organizations to be held accountable for their impact on the environment. Effective corporate social responsibility can earn an organization a positive reputation. The purpose of the research is to determine the impact of sustainability on supply chain management.

\section{Materials and Methods}

The study was facilitated through the systematic review approach. This method of research was utilized to provide the convenience of readily available secondary data while eliminating the both inconvenience and time required to effectively conduct a primary research study.

The secondary data employed in the research study was obtained from online-based research databases like Web of Science and Scopus. Searching strategies like wildcard, truncation, Boolean, and TiAb keywords were utilized to obtain the necessary secondary sources. Under the wildcard searching strategy, both the question mark and pound sign options were utilized. In the truncation phase of the search strategy, only the asterisks were applied. Conversely, in the Boolean searching strategy all the AND, NOT, and OR operators were utilized to obtain data that was narrow and broad at the same time.

Table 1. Search Terms

\begin{tabular}{|l|l|l|l|}
\hline & \multicolumn{1}{|c|}{ AND } & \multicolumn{1}{c|}{ AND } & \multicolumn{1}{c|}{ AND } \\
\hline OR & Sustainability & $\begin{array}{l}\text { Green supply } \\
\text { chain } \\
\text { management }\end{array}$ & $\begin{array}{l}\text { Sustainable } \\
\text { supply chain } \\
\text { management }\end{array}$ \\
\hline OR & Logistics & Manufacturing & Procurement \\
\hline OR & Delivery & Production & Sourcing \\
\hline
\end{tabular}

Finally, the TiAb keyword searching strategy was focused on the title and abstract section of the secondary sources to obtain articles based on keywords such as sustainability and supply chain management.

After the search strategy phase of the study had been completed, 50 potential sources were identified. Next, exclusion and inclusion criteria were applied to obtain secondary data that was highly relevant to the research study. An article was excluded if it was published in a language other than English, or only had the abstract section available for review (i.e., not fully available). All secondary data that was either published within the five preceding years in peer-reviewed journals and that were based on in-depth, sufficient, and detailed research were included in the data pool of the study. Upon completion of the exclusion and inclusion criteria, the data pool of the research study had a total of 13 secondary sources. 
Table 2. Selected Papers

\begin{tabular}{|c|c|c|c|c|}
\hline & Author & Year & $\begin{array}{c}\text { Combination } \\
\text { of search } \\
\text { terms }\end{array}$ & Results \\
\hline 1 & $\begin{array}{l}\text { Neutzling } \\
\text { et al. }\end{array}$ & 2017 & $\begin{array}{l}\text { Sustainable } \\
\text { supply chain } \\
\text { management } \\
\text { and Suppliers }\end{array}$ & $\begin{array}{l}\text { Incorporation } \\
\text { of } \\
\text { sustainability } \\
\text { in a supply } \\
\text { chain leads to } \\
\text { formation of } \\
\text { new } \\
\text { relationships }\end{array}$ \\
\hline 2 & $\begin{array}{l}\text { Trivellas } \\
\text { et al. }\end{array}$ & 2020 & $\begin{array}{l}\text { Green supply } \\
\text { chain } \\
\text { management } \\
\text { and Logistics }\end{array}$ & $\begin{array}{l}\text { Sustainability's } \\
\text { impact is } \\
\text { highest in } \\
\text { logistics. }\end{array}$ \\
\hline 3 & $\begin{array}{l}\text { Taghikhah } \\
\text { et al. }\end{array}$ & 2019 & $\begin{array}{l}\text { Sustainable } \\
\text { supply chain } \\
\text { management }\end{array}$ & $\begin{array}{l}\text { Sustainability's } \\
\text { impact is } \\
\text { highest in } \\
\text { logistics. }\end{array}$ \\
\hline 4 & $\begin{array}{l}\text { Laari et } \\
\text { al. }\end{array}$ & 2018 & $\begin{array}{l}\text { Green supply } \\
\text { chain } \\
\text { management }\end{array}$ & $\begin{array}{l}\text { Sustainability } \\
\text { has a minimal } \\
\text { effect on } \\
\text { financial } \\
\text { position }\end{array}$ \\
\hline 5 & $\begin{array}{l}\text { Katiyar et } \\
\text { al. }\end{array}$ & 2018 & $\begin{array}{l}\text { Sustainability } \\
\text { and } \\
\text { Manufacturing }\end{array}$ & $\begin{array}{l}\text { Sustainability's } \\
\text { impact is } \\
\text { highest in } \\
\text { procurement }\end{array}$ \\
\hline
\end{tabular}

\section{Results and Discussion}

The incorporation of sustainability practices in supply chain management leads to the need to create and develop novel interorganizational relationships with suppliers [13]. Thus, sustainability practices within an organization have a direct and statistically significant impact on linkages within supply chain management. The correlation between sustainability practices and linkages within supply chain management is evident in a research study conducted in Brazil [14]. The study involved Braskem, an organization which is among the highest producers of green polyethylene in South America [15]. Green polyethylene can be understood as a bioplastic that is derived from ethanol, which is extracted from plants [16]. Hence, green polyethylene is highly sustainable, which was the motivating factor behind its production within the organiziation as they had an organizational objective of integrating sustainability in their operations. The direct and statistically significant relationship between sustainability practices and novel suppliers was motivated by the fact that the operations involved mostly required the development of a business line that is different from the core business. Table 1 illustrates search terms. Table 2 shows selected papers regarding the research topic.

The integration of sustainability practices in supply chain management can additionally result in the necessity of altering organizational operations to meet and satisfy the prevailing requirements and scarcities [17]. For instance, a research study conducted within an automobile company in India determined

that sustainability practices can have a positive and direct correlation with the performance levels of supply chain management functions like procurement, manufacturing, and logistics [18]. The correlation between sustainability practices and the supply chain management functions was, however, unequal across these three aspects. Evidence suggests that the relationship between the two variables was strongest from the perspective of procurement or sourcing for raw materials and services [16]. In the supply chain, sustainability practices had an immediate impact on procurement, followed by logistics, then manufacturing. The results obtained in this research study have been further supported by studies conducted in countries such as Iran, China, and the US. The pie chart illustrated in Figure 1 indicates the impact of sustainability practices on procurement, manufacturing, and logistics in the automotive industry.

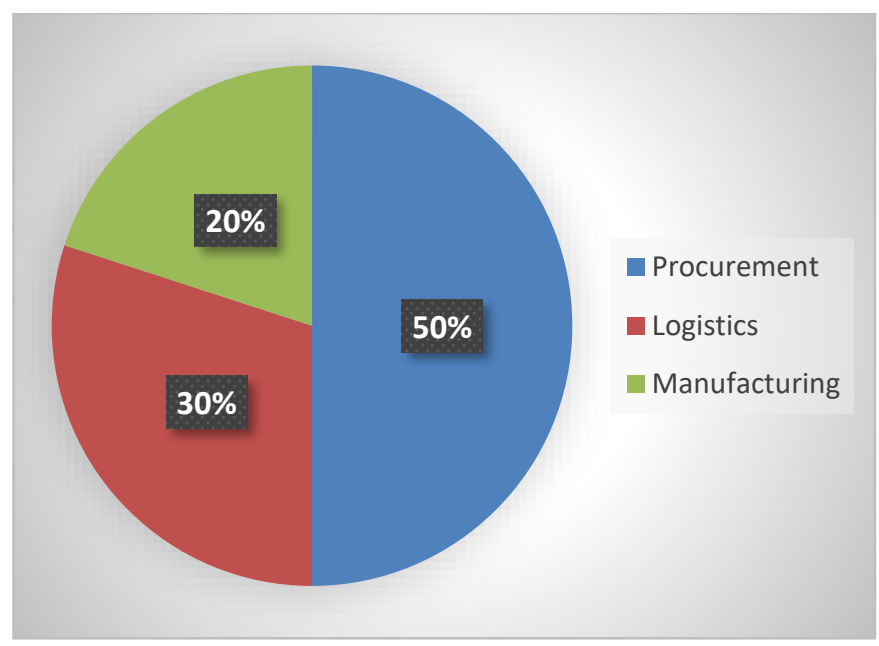

Figure 1. The percentage impact of sustainability practices in the automotive industry

However, a different study determined that the impact of sustainability practices was usually experienced at the highest levels within the logistics phase of the supply chain management. Figure 2 illustrates a hypothesized model that links the relationship between green logistics practices and supply chain performance [17].

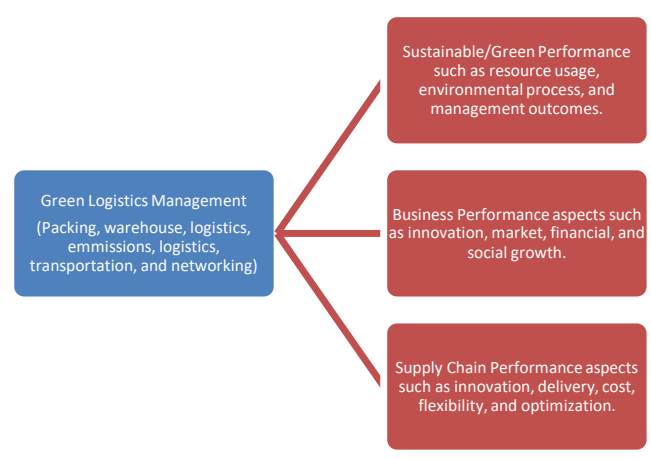

Figure 2: Hypothesized model that links the relationship between green logistics practices and supply chain performance 
The research study stated that logistics is a fundamental step in supply chain management from the environmental and social sustainability perspective [3]. The study further focused on three major processes within logistics: network designing, transporting and distributing. According to the researchers, the reason behind this approach was that these logistical processes have the most significant impact on ecological and social sustainability. In the findings of the research, the researchers state that sustainability practices such as reduced carbon emissions, minimized energy consumption, enhanced societal welfare, optimal labor conditions, and ethical conduct have the highest effect on supply chain management functions.

Application of sustainability practices within supply chain management functions might not lead to significant financial gains. Therefore, there is no direct or positive correlation between profitability and sustainability practices in the short term at an organizational level. Evidence to support this claim was obtained in research facilitated within Finland involving business establishments that are specialized in the provision of logistical services [19]. Based on the theory that this step is the most significant in enhancing environmental sustainability within the supply chain, the researchers studied the logistics phase of supply chain management. In the research study, the researchers determined that organizations that had incorporated sustainability practices in their supply chain might not experience any considerable financial returns. The observation resulted from a lack of both knowledge within the logistics departments and strategies to convert environmental management into a competitive advantage. The researchers additionally noted that organizations that had a higher competitive advantage were more likely to implement various sustainability practices compared to other organizations that lacked a similar advantage [20].

The results obtained in this study from the perspective correlating sustainability and suppliers within the supply chain management could have been motivated by multiple factors. For example, integration of novel sustainability practices requires intensive and extensive sourcing for new raw materials. Further, it is necessary to procure novel services and equipment for sustainability practices to be successfully implemented. Sourcing for novel raw materials, services, and equipment requires organizations to establish different connections with suppliers of these particular resources.

Additionally, the findings obtained in the systematic review from the perspective relating sustainability with organizational operations in the supply chain could have occurred due to various reasons. For example, implementing new sustainability practices generally require logistical support and manufacturing of products that enhance sustainability objectives at an organizational level. The prevailing logistical support and manufacturing processes within a company might not be aligned with the intended sustainability goals. Consequently, novel procedures might be necessary since sustainability is a relatively new practice in supply chain management.

Moreover, the results obtained in the study from the perspective of the correlation between sustainability and financial outcome within supply chain management occur because of multiple factors. However, the most significant motivating factor is that the field of sustainable supply chain management is still relatively understudied.
There is a scarcity of data and information on how sustainability can be utilized to achieve sufficient profitability. This is the major reason behind companies lacking the necessary knowledge and strategies to achieve positive financial outcomes from sustainability practices.

\section{Conclusions and Recommendations}

Overall, it can be determined that sustainability practices have a positive and statistically significant impact on novel suppliers at an organizational level. The higher the intensity of integration of sustainability in supply chain management, the higher the probability of novel suppliers being sourced. Additionally, there is sufficient evidence to show that sustainability practices can lead to a direct effect on organizational operations in the supply chain such as procurement, logistics, and manufacturing. However, it is unclear whether sustainability practices impact procurement or logistics processes more. Finally, statistical data indicated that organizations have yet to develop strategies that can turn sustainability practices into profitable business ventures.

The research was limited in that it was entirely based on secondary sources, as it was a systematic review. The ability to verify the data utilized to facilitate the research study was therefore limited to a significant capacity. This implies there is a probability of researcher bias in the data utilized in this study. Further, the research was limited by the fact that a major portion of the data obtained for the study was collected and published a period preceding the five previous decades. Hence, a lot of it was outdated as the prevailing factors in supply chain management have changed since the field is highly dynamic. This fact further limited the pool of the available and usable data.

Based on the noted limitations, future studies focusing on this particular field should focus on individual sustainability practices like social or environmental sustainability. Previous studies have generally focussed on the entire field of sustainability practices within supply chain management, which undermines the depth and specialization of the acquired findings. Moreover, most of the previous research studies have been facilitated within one geographical area. Due to this, the sufficiency and depth of the research studies are considerably limited, which implies that future research should focus on being multi-centered. 


\section{References}

[1] Zapata, W. Alfredo, and S. Milena Ortiz-Muñoz. "Analysis of meanings of the concept of sustainability," Sustainable Development, vol. 27(1), pp. 153-161, 2019.

[2] L. González, A. Jesús Ángel Coronado Martín, A. C. VacaTapia, and F. Rivas. "How Sustainability Is Defined: An Analysis of 100 Theoretical Approximations," Mathematics, vol. 9(11), pp. 1308, 2021.

[3] T. Firouzeh, A. Voinov, and N. Shukla. "Extending the supply chain to address sustainability," Journal of cleaner production, vol. 229, pp. 652-666, 2019.

[4] What Are the 4 Types of Sustainability? Action for Earth website

[Online].Available: https://www.actionearth.org/what-are-the-4-types-ofsustainability/?v=7516fd43adaa, 2021.

[5] W. Kersten, T. Blecker, and C. M. Ringle, Data Science and Innovation in Supply Chain Management: How Data Transforms the Value Chain, pp. 1-276, 2020.

[6] P. Centobelli, R. Cerchione, and E. Esposito. "Environmental sustainability and energy-efficient supply chain management: A review of research trends and proposed guidelines," Energies, vol. 11(2), pp. 275, 2018.

[7] B. Sezen, and S. Y. Çankaya. "Effects of green supply chain management practices on sustainability performance," J. Manuf. Technol. Manag, vol. 30(1), pp. 98-121, 2019.

[8] M. D'Eusanio, A. Zamagni, and L. Petti. "Social sustainability and supply chain management: Methods and tools," Journal of cleaner production, vol. 235, pp. 178-189, 2019.

[9] W. Brooke. Sustainable Logistics \& Supply Chain Management: Challenges \& Future Outlook. [Online]. Available:

https://minds.wisconsin.edu/bitstream/handle/1793/78885/C urioso,\%20Gary.pdf? sequence $=1,2018$.

[10] H. Ahmadi, H. Lo, H. Gupta, S. Kusi-Sarpong, and J. Liou. "An integrated model for selecting suppliers on the basis of sustainability innovation," Journal of Cleaner Production, vol. 277, pp. 123261, 2020.

[11] M. Nutburn, Five benefits of a sustainable supply chain. CIPS [Online]. Available: https://www.cips.org/supplymanagement/opinion/2019/july/five-benefits-of-a-sustainablesupply-chain/, 2019

[12] M. Irfan, M. Hassan, and N. Hassan. "Unravelling the fuzzy effect of economic, social and environmental sustainability on the corporate reputation of public-sector organizations: A case study of Pakistan," Sustainability, vol. 10(3), pp. 769, 2018.

[13] L. A. Fish, C. Bratt, R. Sroufe, and G. Broman. (2017) Implementing Strategic Sustainable Supply Chain Management [Online]. Available: https://www.divaportal.org/smash/get/diva2:1584456/FULLTEXT01.pdf

[14] D. M. Neutzling, A. Land, S. Seuring, and L. F. Machado do Nascimento. "Linking sustainability-oriented innovation to supply chain relationship integration," Journal of Cleaner Production, vol. 172, pp. 3448-3458, 2018.

[15] J. F. P. Santos, K. D. Macario, R. M. Jou, F. M. Oliveira, R. P. Cardoso, M. Diaz, R. M. Anjos, and E. Q. Alves. "Monitoring the biogenic fraction of sugarcane-based plastic bags," Journal of cleaner production, vol. 233, pp. 348-352, 2019.

[16] P. Trivellas, G. Malindretos, and P. Reklitis, Implications of Green Logistics Management on Sustainable Business and Supply Chain Performance: Evidence from a Survey in the
Greek Agri-Food Sector, 2020 [Online]. Available: https://doi.org/10.3390/su122410515

[17] S. D. Allen, Q. Zhu, and J. Sarkis. Expanding conceptual boundaries of the sustainable supply chain management and circular economy nexus, 2021 [Online]. Available: https://doi.org/10.1016/j.clscn.2021.100011

[18] R. Katiyar, L. M. Purushottam, M. K. Barua, R. Tibrewala, and G. Kumar. "Impact of sustainability and manufacturing practices on supply chain performance: Findings from an emerging economy," International Journal of Production Economics, vol. 197, pp. 303-316, 2018.

[19] S. Laari, J. Töyli, and L. Ojala. "The effect of a competitive strategy and green supply chain management on the financial and environmental performance of logistics service providers," Business Strategy and the Environment, vol. 27(7), pp. 872-883, 2018.

[20] O. M. Hamdy, K. K. Elsayed, and B. Elahmady. "Impact of Sustainable Supply Chain Management Practices on Egyptian Companies' Performance," European Journal of Sustainable Development, vol. 7(4), pp. 119-130, 2018 